\title{
Temporal Analysis of Water Quality in the Straits of Johor
}

\author{
Analisis Terhadap Masa ke atas Kualiti Air di Selat Johor \\ Firdaus Mohamad Hamzah*, Othman Jaafar, Muhammad Imran Mohd Junaidi \& Azrul A. Mutalib
}

\begin{abstract}
Temporal analysis is used to obtain changes in water quality along the Straits of Johor. Boxplot is used to show graphically on the temporal pattern of yearly and monthly temperature, conductivity, $\mathrm{pH}$, dissolved oxygen (DO), total suspended solids (TSS) and oil and grease in the water from 2003 to 2013. The ANOVA test is carried out to determine the significance of the mean of each parameter between years. The boxplot shows a particular trend for each of the marine parameters over the year and the seasonal pattern is only apparent in temperature. The ANOVA test indicates a significant difference in the means of each water quality marine parameter across the year. The changes in each of the marine parameters over the year could be associated to the natural features of the marine water and climate change. The seasonal pattern however is only apparent in temperature which could be influenced by the monsoon seasons.
\end{abstract}

Keywords: Temporal Analysis; Straits of Johor; water quality; ANOVA

\section{ABSTRAK}

Analisis terhadap masa digunakan untuk melihat perubahan dalam kualiti air di sepanjang Selat Johor. Plot kotak digunakan untuk menunjukkan corak perubahan suhu, kekonduksian, pH, oksigen terlarut, jumlah pepejal terampai dan minyak di dalam air dari tahun 2003 hingga 2013. Ujian ANOVA dijalankan bagi menentukan kesignifikan purata bagi setiap parameter antara tahun. Plot kotak menunjukkan tren tertentu bagi setiap parameter marin sepanjang tahun dan corak bermusim hanya jelas bagi suhu air. Ujian ANOVA menunjukkan terdapat perbezaan purata yang signifikan bagi setiap parameter kualiti air marin antara tahun.

Kata kunci: Analisis Terhadap Masa; Selat Johor; kualiti air; ANOVA

\section{INTRODUCTION}

Most of the productive marine ecosystems in the world can be found in the coastal environments and wildlife area of linkages. Changes in water quality can be disastrous to the marine ecosystems and it is not suitable for the survival of endangered species due to circumstances that are no longer suitable for their survival (Bierman et al. 2011). Changes in water quality may also pose a threat to humans through changes in waters used for recreation, fisheries and industry.

Quantitative analysis via statistical technique may allow better understanding on the water quality whereby it can provide scientific guidelines for managing the water resources (Helsel \& Hirsch 2002; Hirsch et al. 1982). For example, the use of nonparametric statistics is appropriate in the case of non-normal distribution in water quality parameters (Doering 1996; Doering \& Chamberlain 1999). This gives a better knowledge of its temporal state with regards to future evolution and forecasts (Berzas et al. 2000; R. Bouza-Dean et al. 2008; Simeonov et al. 2002; Simeonov et al. 2003).

In this study, the monthly measurements of six marine water quality parameters including temperature, conductivity, $\mathrm{pH}$, dissolved oxygen (DO), total suspended solids (TSS) and oil and grease taken from 2003 to 2013 along the Straits of Johor are explored. The data sets were provided from the Earth Observation Centre (EOC), National University of Malaysia (UKM). The first objective of this study is to explore the trend and seasonal pattern of marine parameters and second objective is to determine the differences of the concentrations for each parameter between years.

\section{MATERIAL AND METHOD}

The study area is located at Johor Straits in between the southern of Johor, Peninsular Malaysia and Singapore. Figure 1 depicted nature of Johor Straits which is relatively narrow and shallow waterways.

The dimensions of the straits encompass about six kilometers wide and twenty-five meters deep. It has long been important to the human resources and the opportunity for the two countries for shipping (Wood et al. 1997).

The straits connect the continental shelf in the South China Sea in the eastern part with the Strait of Malacca in the western part. The beaches on both sides of the straits in Malaysia and Singapore are suitable for tourism and recreational areas as a source of stimulating the economy. Johor Bahru City and Singapore are big cities along the 
Straits of Johor which results in the occurrence of high pollution (Behera et al. 2013).

Both region (Malaysia and Singapore) installed two small culverts near the embankment and as the water flow approaches close to zero resulting the fine sediment to settle to the bed of the straits. Waste discharges from both countries into the causeway tend to gather due to the low water flow which restricts the dispersion to both eastern and western ends of the straits.

In this study, twelve water quality monitoring stations (Figure 1) have been chosen and six marine water quality parameters have been selected, along the Straits of Johor. The water quality parameters are temperature, electrical conductivity (EC), $\mathrm{pH}$, dissolved oxygen (DO), total suspended solids (TSS), oil and grease (OG).

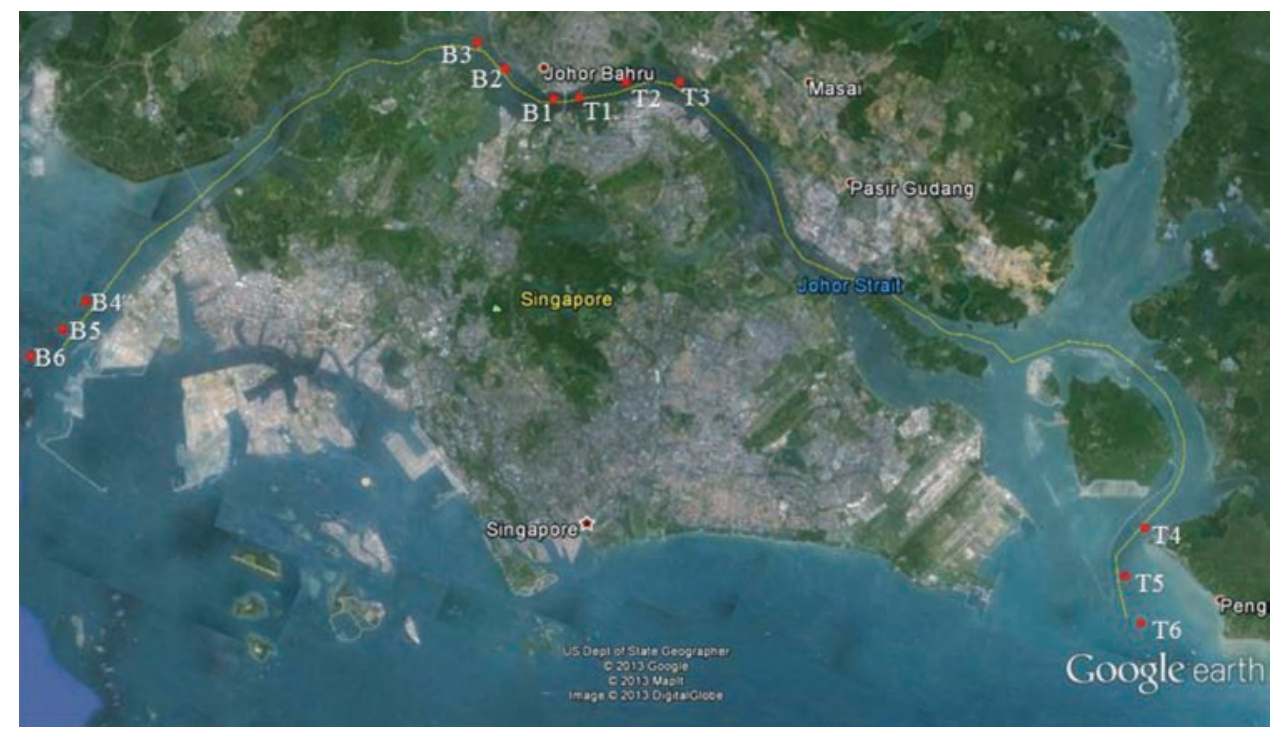

FIGURE 1. Location of the study area and water quality monitoring stations

STATISTICAL ANALYSIS

Boxplot is used to explore trend and seasonal pattern of the marine parameters from 2003 to 2014. The One - Way Analysis of variance (ANOVA) is applied to determine the differences in the mean of each parameter between years (Hongmei Bu et al. 2010; Mendiguch' A et al. 2007) since it allows a comparison of more than two years of each marine parameter. The F statistic which represents the ratio of the variance between years and variance within years for a given marine paremeter is computed. follows:

Two hypotheses are determined and they are tested as

$H_{0}$ : There are no significant differences in means of a marine water quality parameter for more than 2 years.

$H_{1}$ : There are significant differences in means of a marine water quality parameter for more than 2 years.

If p-value $<\alpha=0.05, H_{0}$ is rejected and it shows that there are significant differences in means of a given marine parameter for more than 2 years.

\section{RESULTS}

The temporal pattern of the marine parameters was explored using boxplot as shown in Figures 2 and 3. Figure 2 shows the boxplot for each marine parameter over the year.
Temperature, $\mathrm{pH}$ and total suspended solids are moderately constant over the year, conductivity shows a cyclical pattern over the year, dissolved oxygen declines over the year while oil and grease is constant except in 2013.

Figure 3 shows the boxplot for the six marine parameters for each month. The mean temperature shows an apparent seasonal pattern since the temperature increases from January until June and decreases afterwards to the end of the year. The highest mean value $\left(\sim 30.5^{\circ} \mathrm{C}\right)$ in May and the lowest mean $\left(\sim 28.3^{\circ} \mathrm{C}\right)$ in December are shown from the diagram. In contrast, the remaining parameters show no clear seasonal pattern from January until December.

Table 1 shows the result of ANOVA test for each parameter across the year. The F-value for each parameter is higher than 1 , indicating that the variance between years are higher than

TABLE 1. ANOVA results based on the spatial and temporal

\begin{tabular}{cccc}
\hline \multirow{2}{*}{ Parameter } & \multicolumn{3}{c}{ Temporal (Year) } \\
\cline { 2 - 4 } & F Value & df & P-Value \\
\hline Temperature & 8.151 & 10,1213 & 0.000 \\
Conductivity & 62.366 & 10,1213 & 0.000 \\
pH & 31.630 & 10,1213 & 0.000 \\
Dissolved Oxygen & 38.516 & 10,1213 & 0.000 \\
Total Suspended Solids & 37.344 & 10,1197 & 0.000 \\
Oil and Grease & 42.945 & 10,1197 & 0.000 \\
\hline
\end{tabular}



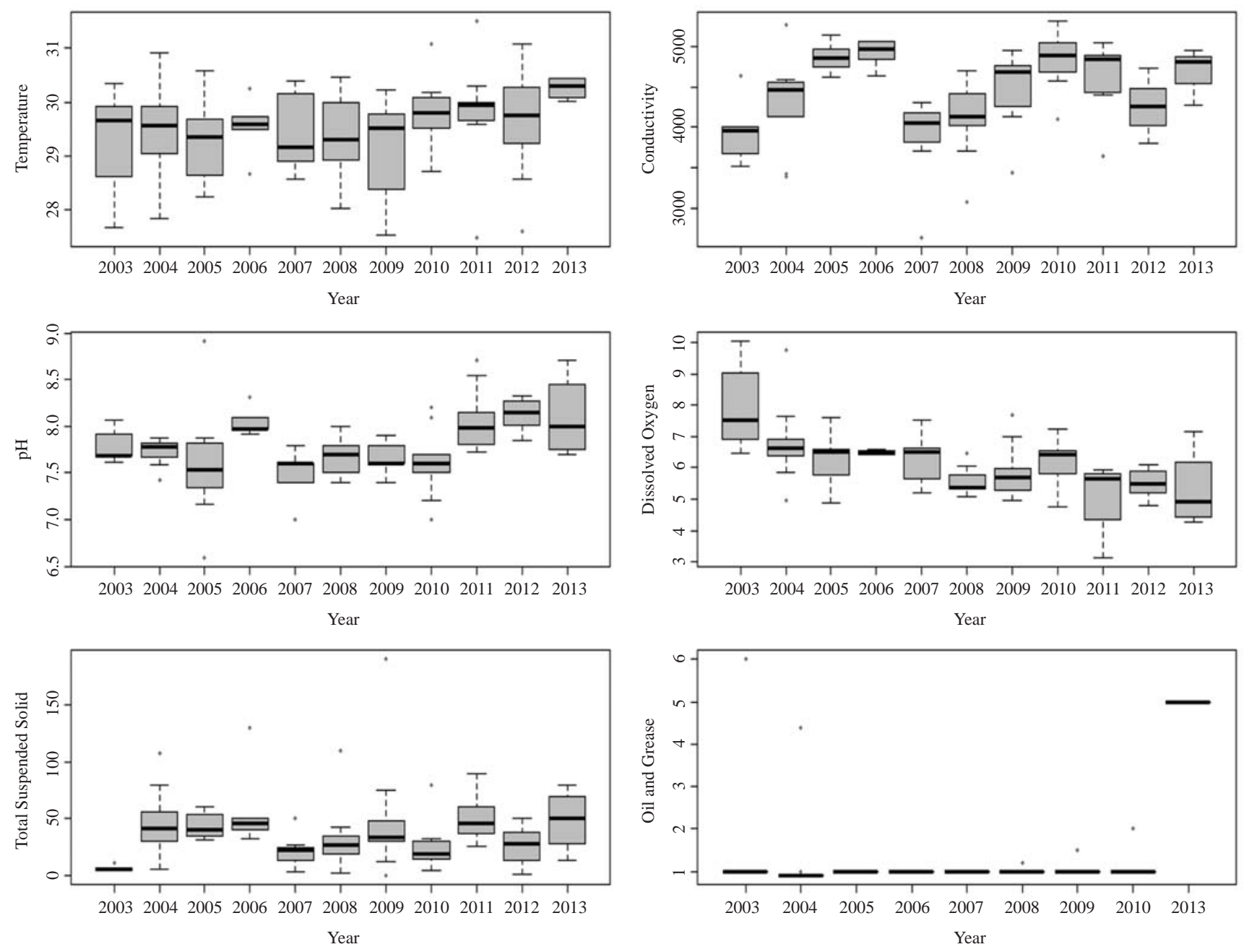

FIGURE 2. Boxplot of six marine parameters over the year

within year. The low p-values $(<0.05)$ clearly show evidence of the significant differences in mean for each parameter across the year.

\section{DISCUSSION}

According to the Environmental Protection Agency United States (USEPA), sea temperature is increasing in $20^{\text {th }}$ century. Data shows from 1901 to 2012, the temperature rose at an average rate of $0.1^{\circ} \mathrm{C}$ per decade. Therefore, it can be said that the increase of temperature in the Straits of Johor could be affected by rising sea temperatures worldwide. The Ocean Health Index (OHI) also noted a major cause of increased levels of marine water temperature around the world is a global climate warming due to excessive greenhouse gases released into the atmosphere. Hence, the rapid development near the Straits of Johor may result in increase of greenhouse gases which contribute to global climate warming. According to Behera et al. (2013) high sea surface temperature occurred in between the monsoon season which is from April to May and October to November. The temperature is low in the northeast monsoon season which lasts from November to
March and the southwest monsoon which lasts from June to September. Therefore, the seasonal pattern in temperature in the Straits is influenced by the southwest monsoon and northeast monsoon. The higher intensity of rainfall during the southwest monsoon contribute to the high flow from the river to the Straits of Johor which leads to the lowest mean temperature $\left(\sim 27.9^{\circ} \mathrm{C}\right)$ around January. The reduction in rainfall results in increase of the water temperature during the monsoon seasons with the highest mean monthly temperature of about $31^{\circ} \mathrm{C}$ in May.

For conductivity, there is no effect of seasonality shown throughout the year. According to Ronal L. Miller (1988), the conductivity may increase by 2 to 3 percent for every increase of $1^{\circ} \mathrm{C}$ in temperature. However, no such relationship is observed between the two parameters. Therefore, there could be other factor that may contribute to the feature of conductivity. Salinity is likely to influence the changes in conductivity as it affects the conductivity in the presence of ions.

Water $\mathrm{pH}$ showed significant differences over the year in which it is not influenced by seasonality feature. According to the National Oceanic and Atmospheric Administration United States (NOAA), most aquatic organisms living in water 

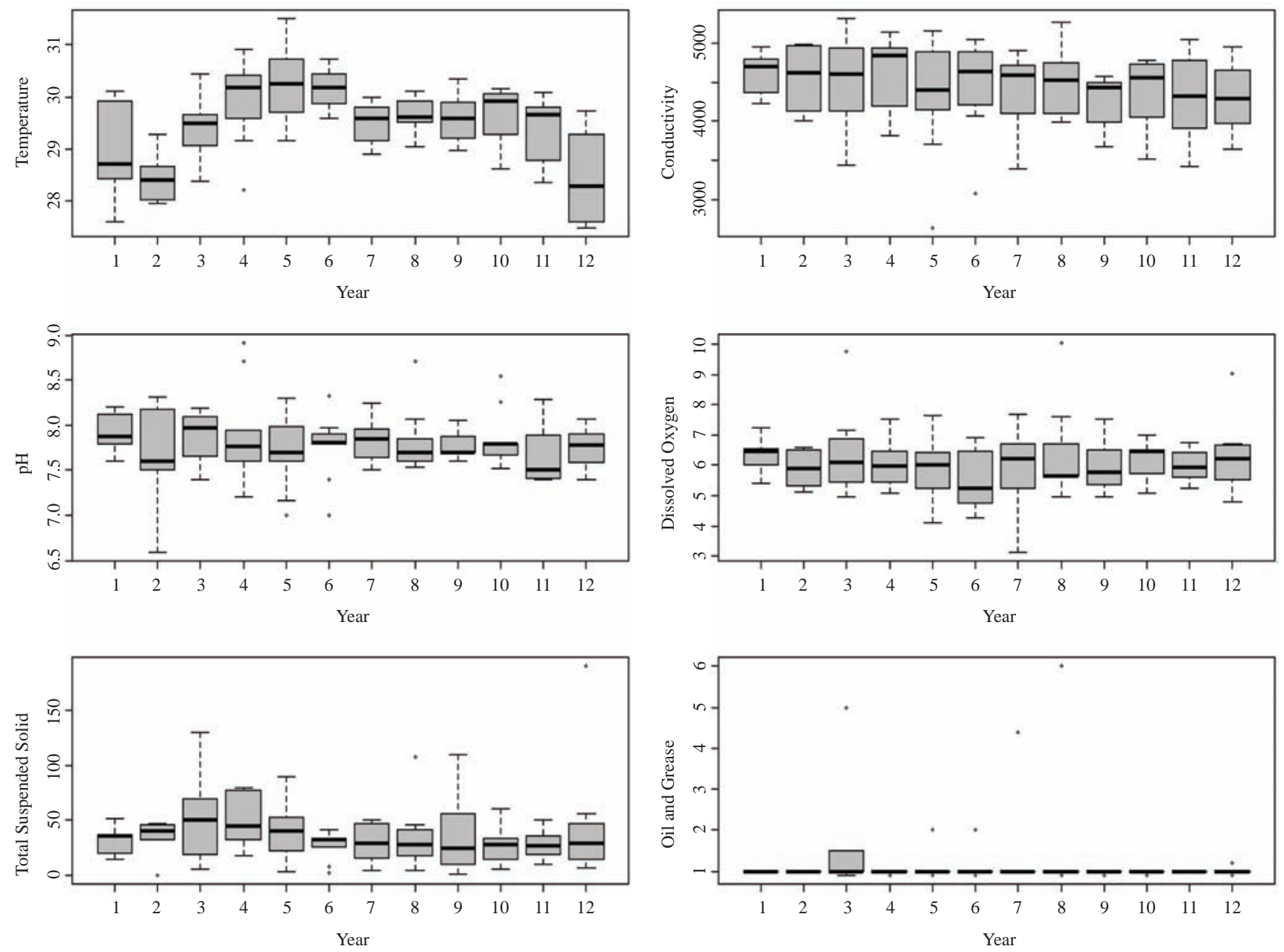

FIGURE 3. Boxplots of marine parameters for each month

with a $\mathrm{pH}$ between 5.0 and 9.0. The $\mathrm{pH}$ value in the strait tends to remain at the same level as chemical components in seawater resist large changes in $\mathrm{pH}$. However, the biological activity can alter the $\mathrm{pH}$ in the strait with a sudden occurrence of photosynthesis (Doney 2010; Re'Rolle et al. 2012). Therefore, $\mathrm{pH}$ in the Johor Straits is is at about neutral levels ( $7.62-\sim 8: 27)$ and this indicates a lack of photosynthetic activity in the water.

Dissolved oxygen shows a decreasing pattern over the year. The dissolved oxygen is the waste product of photosynthesis of aquatic plants (Nybakken \& Wallace 1992). The lack of photosynthesis process in the water may cause the reduction of dissolved oxygen. According to Boyd (1979), the low oxygen absorption in natural waters occurred in a case of strong turbulence. Hence, the decline of dissolved oxygen could also be due to the lack of turbulence in the Straits of Johor. The low turbulence was probably due to the embankment built with only two culverts that allowing the water flow from the west to the east of Straits of Johor and as a consequence, the natural current is disturbed. The decrease of dissolved oxygen could also be influenced by the changes in water temperature. In particular, the solubility of oxygen decreases as water temperatures increases.
For total suspended solids, it can be seen that it is not influenced by the seasonal variability of the southwest monsoon and northeast monsoon. This occurrence is probably due to low water flow in the Straits of Johor and causes the suspended solids to easily settle at the bottom of the water. The embankment of highway and railway may disrupt the water flow.

There is no effect the seasonal variability in oil and grease. The decrease of oil and grease in water is at the proper level according to the standard provided by the Interim Marine Water Quality Standards (IMWQS). This reduction is probably due to the improvement of sewerage system in Johor Bahru and lack of domestic waste disposal into the river.

\section{CONCLUSSION}

Temporal analysis shows a particular trend for each of the marine parameters over the year. There are few parameters that behave similarly across the year as indicated by their similar patterns, indicating that there is an interaction between marine parameters over the year. The changes in each of the marine parameters over the year could be associated to the 
natural features of the marine water and climate change. The seasonal pattern however is only apparent in temperature which could be influenced by the monsoon seasons.

\section{ACKNOWLEDGEMENTS}

The authors would like to thank the Ministry of Higher Education (MOHE) for supporting this work via research grant, FRGS/1/2013/SG04/UKM/02/3 and AP-2015-011. Special appreciation is given to the Institute of Climate Change (IKLIM) UKM for providing the data.

\section{REFERENCES}

Behera, M. R., Chun, C., Palani, S. \& Tkalich, P. 2013. Temporal variability and climatology of hydrodynamic, water property and water quality parameters in the West Johor Strait of Singapore. Marine Pollution Bulletin 77(2013): 380-395.

Berzas, J. J., Garc1'A, L. F., Rodrı'Guez, R. C. \& Martı'NAlvarez, P. J. 2000. Evolution of the water quality of a managed natural wetland: Tablas De Daimiel National Park. Water Research 34: 3161-3170.

Bierman, P., Lewis, M., Ostendorf, B. \& Tanner, J. 2011. A review of methods for analysing spatial and temporal patterns in coastal water quality. Ecological Indicators 11: 103-114.

Bouza-Dean, R. M. Ternero-Rodrı'Guez \& Ferna'NdezEspinosa, A. J. 2008. Trend study and assessment of surface water quality in the Ebro River (Spain). Journal of Hydrology 361: 227-239.

Doering, P. H. 1996. Temporal variability of water quality in the St. Lucie Estuary, South Florida. Water Resouces Bulletin 32(6): 1293-1306.

Doering, P. H. \& Chamberlain, R. H. 1999. Water quality and source of freshwater discharge to the Caloosahatchee Estuary, Florida. Journal of the American Water Resources Association 35: 793-806.

Doney, S. C. 2010. The growing human footprint on coastal and open-ocean biogeochemistry. SCIENCE 328 (2010): 1512-1516.

Helsel, D. R. \& Hirsch, R. M. 2002. Statistical methods in water resources techniques of water resources investigations. U.S. Geological Survey 4(3): 522.

Hirsch, R. M., Slack, J. R. \& Smith, R. A. 1982. Techniques of trend analysis for monthly water quality data. Water Resources Research 18(1): 107-121.

Hongmei Bu, Xiangtan, Li, S. \& Quanfa Zhang. 2010. Temporal and spatial variations of water quality in the Jinshui River of the South Qinling Mts., China. Ecotoxicology and Environmentals 10: 1016.

Mendiguchı'A, C., Moreno, C. \& Garcı'a-Vargas, M. 2007. Evaluation of natural and anthropogenic influences on the Guadalquivir River (Spain) by dissolved heavy metals and nutrients. Chemosphere 69: 1509-1517.

Nybakken, J. W. \& Wallace, R. L. 1992. Marine biology: An ecological approach. Marine Biology 1: 496.

Piaw, C. Y. 2009. Statistik Penyelidikan Lanjutan: Ujian Univariat Dan Multivariat. Buku 4. McGraw-Hill (Malaysia) Sdn. Bhd.

Pintoa, R., Patrícioa, J., Baetaa, A., Fathb, B. D., Netoa, J. M. \& Marquesa, J. C. 2009. Review and evaluation of estuarine biotic indices to assess benthic condition. Ecological Indicators 9(1): 1-25.

Re'Rolle, V. M. C., Floquet, C. F. A., Mowlem, M. C., Bellerby, R. R. G. J., Connelly, D. P. \& Achterberg, E. P. 2012. Seawater-Ph measurements for ocean-acidification observations. Trends in Analytical Chemistry 40: 146157.

Ronald L. Miller, W. L. B. \& Norman E. Peters. 1988. Specific conductance: Theoretical considerations and application to analytical quality control. U.S. GEOLOGICAL SURVEY WATER-SUPPLY PAPER 2311.

Simeonov, Einax J., Stanimirova, I. \& Kraft, J. 2002. Environmetric modelling and interpretation of river water monitoring Data. Analytical and Bioanalytical Chemistry 374(5): 898-905.

Simeonov, J.A., Stratis, C., Samara, G., Zachariadis, D., Voutsa, A., Anthemidis, M., Sofoniou \& T. Kouimtzis. 2003. Assessment of the surface water quality in Northern Greece. Water Research 37: 4119-4124.

Wood, A. K. H., Ahmad, Z., Azhar, N., Shazili, M., Yaakob, R. \& Carpenter, R. 1997. Geochemistry of sediments in Johor Strait between Malaysia and Singapore. Continental Shelf Research 17(10): 1207-1228.

Firdaus Mohamad Hamzah

Othman Jaafar

Muhammad Imran Mohd Junaidi

Azrul A. Mutalib

Department of Civil and Structural Engineering

Faculty of Engineering and Built Environment

43600 UKM Bangi, Malaysia

Phone: + 603 - 89216506

Email address: fir@ukm.edu.my 
